\title{
Analysis of the Influence of Coordination and Supervision in Right to Cultivate Issuance Service on the Performance of Plantation Companies in Jambi Province
}

\author{
Sarimah M. Rachmad R Edward Shofia Amin \\ Economy Faculty, Jambi University, Indonesia
}

\begin{abstract}
Right to Cultivate (HGU or Hak Guna Usaha) as a legal capital for a plantation business takes a long time to be issued because getting permits as one of the requirements from various institutions is complicated in-process and expensive. This affects the quality of issuance service and comfort for HGU holders to invest and improve their performance in business activities. This study aims to describe and analyze the coordination between agencies related to the issuance of HGU, internal supervision of agencies related to the issuance of HGU, services of HGU issuance, and the performance of HGU holders in Jambi Province. Methodologically, this research fulfills descriptive, explanatory, and exploratory objectives. The population of the study is 120 plantation companies that have obtained HGU in Jambi Province, and there are 165 respondents. Hypothesis testing uses Structural Equation Modeling (SEM). The results of the study show that the coordination between agencies related to the issuance of HGU and the supervision of related agencies positively and significantly affects the service of HGU issuance and the performance of HGU holder companies in Jambi Province. However, those elements have not conducted as expected.
\end{abstract}

Keywords: Coordination, Supervision, Service, Company's Performance

DOI: $10.7176 / \mathrm{JESD} / 10-22-12$

Publication date: November $30^{\text {th }} 2019$

\section{Introduction}

The economy of Jambi Province based on the Gross Regional Domestic Product (GRDP) in 2018 reached Rp. 208,378.55 billion and GRDP per capita reached Rp. 58.36 million. The economy growth of Jambi Province in 2018 compared to the previous year was 4.71 percent. The plantation sector contributed $17.2 \%$ of the total GRDP of Jambi Province, which absorbed 649,959 households with its leading commodities were rubber and palm oil, and there were 186 plantation companies in Jambi Province.

To acquire the land needed by the company to carry out its business activities for investment, the company must have a Location Permit, and Location Permit must be upgraded to Plantation Business License (IUP or Izin Usaha Perkebunan). Location Permit in Jambi Province is granted for 1,368,883.15 hectares of land, while IUP is granted for $962,042.10$ hectares of land. This means that there is an area of 406,841.10 hectares of land owned by plantation companies that are not IUP land. The cultivated area owned by plantation companies is $603,185.55$ hectares. If it is compared to the area with IUP, there is a big difference of $358,856.55$ hectares. According to Article No 32 of PERMENTAN 98/2013, if plantation companies that have obtained IUP are no longer able to obtain additional land, then there must be a reduction of land area in their IUP. This activity requires better coordination between the Regency Government and the Land Office to synchronize data related to the reduced area in IUP. This is related to the land area in HGU issued by the Land Office as the agency providing service of HGU issuance to plantation companies.

The area of HGU land in Jambi Province until August 2019 is 255,228.226 hectares, and the area of IUP land is $962,042.10$ hectares. There are 706,813.874 hectares (73.5\%) of land with Plantation Business License but without HGU yet. According to Law Number 39/2014 concerning Plantations, after IUP is granted, it is obligatory to upgrade the status of land to HGU and HGU is required in order to expand investment in the plantation sector.

In order to maintain the goal, organizations need to find an efficient coordination mechanism to deal with the complexity. Coordination can be achieved through various advanced coordination methods and frameworks, as described by Thompson, 1967; Malone \& Crowston, 1994; March \& Simon, 1958; van de Ven, Delbecq, and Koenig, 1976; Mintzberg, 1979. Galbraith (1977) stated that coordination aimed to reduce complexity by managing information and that the success of a company depended very much on its ability to efficiently handle its information process. From the perspective of agency, the main benefits of coordination are to eliminate less efficient services and to refocus resources on providing new services or expansion. There are some obstacles that make coordination difficult, such as obstacles due to bureaucracy and authority of organization. These obstacles become barrier to the formation and management of coordination. Therefore, this study is designed to look at the coordination in the issuance of Right to Cultivate (HGU) in Jambi Province, where coordination is carried out by two or more agencies or institutes. These agencies have high diversity and are interdependent, so good coordination is necessary. Without good coordination, conflicts and problems are bound to happen. 
Service of HGU issuance is one of the government services in the field of land and carried out by a crosssectoral collective mechanism. This mechanism is carried out by the government and the community, such as the Indonesian National Land Agency (Badan Pertanahan Nasional), the Provincial Plantation Office and Environment and Forestry Agency, the Regency Government, the community and non-governmental organizations (NGOs) based on the authority they have. In relation to the development of land in Jambi Province involving various agencies, both public (agencies/institutions), private organizations, and community organizations, coordination is needed to manage the relations of various sectors and related stakeholders. Coordination between agencies involved in land development determines the success of land development because there are many interests of cross-sectors and organizations that need to be directed towards a common goal. Therefore, it will be difficult in realizing synergy without coordination in the efforts of land development.

To obtain a Right to Cultivate (HGU), the company must meet the requirements based on the Regulation of the Ministry of Agrarian Affairs and Spatial Planning/Head of National Land Agency of the Republic of Indonesia Number 4 of 2017 regarding Services Standards of the Ministry of Agrarian Affairs and Spatial Planning/National Land Agency. HGU issuance service follows the standards of the regulation, and it is also followed by supervision. Supervision increases the effectiveness of organizations, especially public organizations that provide services to the community. Supervision is imposed on bureaucratic organizations, although organizations may have the capacity to take certain policies effectively. The direct application of this authority will result in coordination and in the development of procedural mechanisms (such as Standard Operating Procedure/SOP) to achieve the common goal. In some cases, this mechanism may only require one program that provides other information about their actions. By granting Right of Cultivate (HGU) in accordance with the implemented regulations to companies, companies are expected to be more focused on doing business and carrying out their rights and obligations as the HGU holders. If the obligations have been carried out, the company's performance should improve and have an impact on improving their company's economy in particular, and people's economy in general.

There are several objectives in this study, namely (1) to describe the coordination between agencies/institutions related to $\mathrm{HGU}$ issuance, internal supervision of agencies/institutions related to $\mathrm{HGU}$ issuance, services of HGU issuance, and the performance of HGU holders in Jambi Province, (2) to analyze the influence of coordination between these agencies/institutions on the service of HGU issuance, (3) to analyze the influence of internal supervision of related agencies/institutions on the service of HGU issuance in Jambi Province, (4) to analyze the influence of coordination between related agencies/institutions on the performance of companies as HGU holders in Jambi Province, and (5) to analyze the influence of the service of HGU issuance on the performance of plantation companies in Jambi Province.

\section{Methods}

The samples for the study are 53 companies that have obtained HGU (HGU holders). Respondents in this study were randomly assigned to 3 people for each selected company, so the total number of respondents selected was 165 respondents. The data for this study consist of quantitative and qualitative data. Sources of data were obtained from primary data and secondary data. A structured questionnaire was carried out to obtain primary data.

Descriptive Statistics were carried out to describe the characteristics of respondents, samples, and research variables. Answer options start from number 1 to number 5 because the scale used in this study is Likert scale of $1-5$. Categorization is carried out to determine the range of it. Then it is obtained that the Scale Range is 132, the lowest score is 165 , and the highest score is 825 . Unidimensionality testing is carried out by having Confirmatory Factor Analysis (CFA) with AMOS 16.0. The theoretical model is described in a path diagram in two groups, namely Exogeneous Construct and Endogeneous Construct. Structural Equation was carried out to describe the relationship between variables. The measurement model was used to determine variables as well as determine a series of matrices in order to show correlation between variables. 
Figure 1. Path Diagram

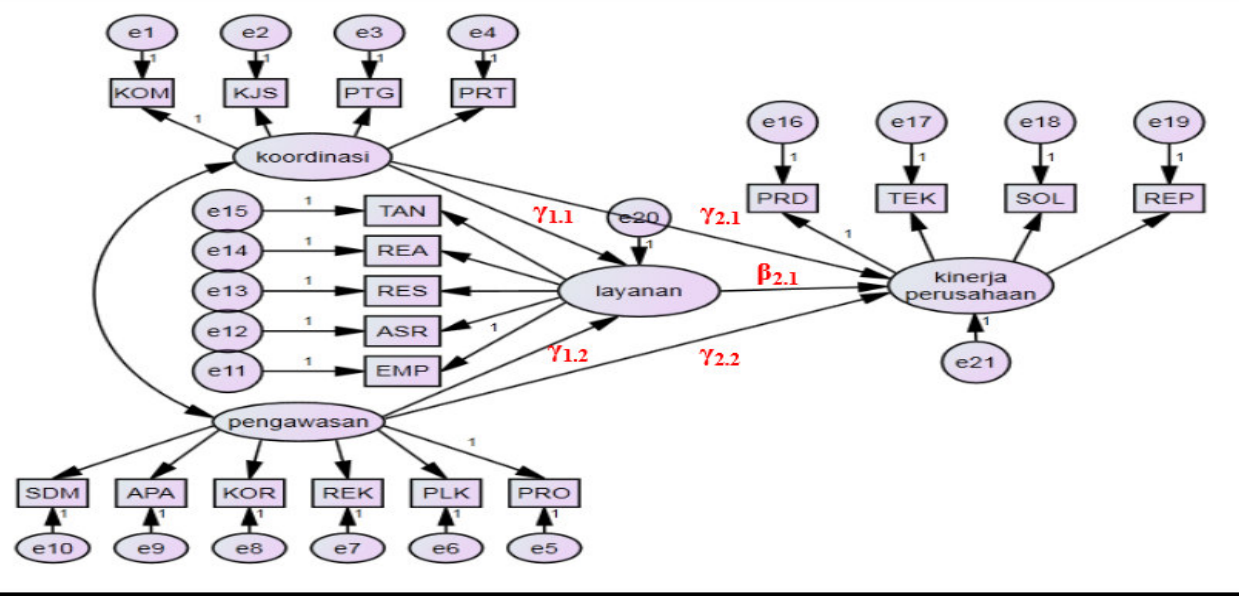

Source: Processed for research

Some goodness of fit indices and cut-off value to test whether a model can be accepted or rejected are as follows:

Table 1 Goodness of Fit Indices and Cut-off

\begin{tabular}{|l|c|}
\hline \multicolumn{1}{|c|}{ Goodness of Fit Indices } & Cut - Off Value \\
\hline Chi Square & Expected to be low \\
Significance Probability & $\geq 0,05$ \\
RMSEA & $\leq 0,08$ \\
GFI & $\geq 0,90$ \\
AGFI & $\geq 0,90$ \\
CMIN/DF & $\leq 2,00$ \\
TLI & $\geq 0,95$ \\
CFI & $\geq 0,95$ \\
\hline
\end{tabular}

Indicator variables used in this study are briefly described in Table 2 .

Table 2. Variables, Operational Definition, Indicator Variables, Measurement, Scale and Item Number

\begin{tabular}{|c|c|c|c|c|c|c|}
\hline No & Variable & Definition & Indicator Variables & Measurement & Scale & $\begin{array}{c}\text { Item } \\
\text { Number }\end{array}$ \\
\hline \multirow[t]{4}{*}{1} & \multirow[t]{4}{*}{ Coordination } & \multirow{4}{*}{$\begin{array}{l}\text { The degree to which the institution } \\
\text { related to the HGU application } \\
\text { requirements is able to establish } \\
\text { cooperation with companies as the } \\
\text { HGU holders as well as the HGU } \\
\text { issuer so that it can run as expected. }\end{array}$} & Communication & 1 to 5 & Interval & 1 to 2 \\
\hline & & & Cooperation & 1 to 5 & Interval & 1 to 2 \\
\hline & & & Task distribution & 1 to 5 & Interval & 1 to 2 \\
\hline & & & Meetings & 1 to 5 & Interval & 1 \\
\hline \multirow[t]{6}{*}{2} & \multirow[t]{6}{*}{ Supervision } & \multirow{6}{*}{$\begin{array}{l}\text { The degree to which the institution } \\
\text { related to the management of HGU } \\
\text { is able to process the various factors } \\
\text { related to the HGU issuance }\end{array}$} & Programs & 1 to 5 & Interval & 1 to 2 \\
\hline & & & Implementation & 1 to 5 & Interval & 1 to 2 \\
\hline & & & Permit recommendation & 1 to 5 & Interval & 1 to 2 \\
\hline & & & Permit implementation & 1 to 5 & Interval & 1 \\
\hline & & & $\begin{array}{l}\text { Increase on the ability of } \\
\text { apparatus }\end{array}$ & 1 to 5 & Interval & 1 \\
\hline & & & Human resources condition & 1 to 5 & Interval & 1 to 2 \\
\hline \multirow[t]{5}{*}{3} & \multirow{5}{*}{$\begin{array}{l}\text { Service of } \\
\text { HGU issuance }\end{array}$} & \multirow{5}{*}{$\begin{array}{l}\text { A series of activities that occur as a } \\
\text { result of interaction between the } \\
\text { HGU holders and the HGU issuer in } \\
\text { order to get a satisfaction although } \\
\text { the results are not physically bound } \\
\text { to the product }\end{array}$} & Tangible & 1 to 5 & Interval & 1 to 5 \\
\hline & & & Reliability & 1 to 5 & Interval & 1 to 2 \\
\hline & & & Responsiveness & 1 to 5 & Interval & 1 to 2 \\
\hline & & & Assurance & 1 to 5 & Interval & 1 to 2 \\
\hline & & & Empathy & 1 to 5 & Interval & 1 to 5 \\
\hline \multirow[t]{4}{*}{4} & \multirow{4}{*}{$\begin{array}{l}\text { Performance } \\
\text { of Company }\end{array}$} & \multirow{4}{*}{$\begin{array}{l}\text { The degree to which a company } \\
\text { manages existing resources in a } \\
\text { given period so that it can generate } \\
\text { results by referring to the } \\
\text { implemented standards }\end{array}$} & Productivity & 1 to 5 & Interval & 1 to 2 \\
\hline & & & $\begin{array}{l}\text { Response to changes in } \\
\text { technology }\end{array}$ & 1 to 5 & Interval & 1 to 2 \\
\hline & & & Problem Solving & 1 to 5 & Interval & 1 to 5 \\
\hline & & & Company's reputation & 1 to 5 & Interval & 1 to 2 \\
\hline
\end{tabular}

Source: Processed for the research

\section{Results and Discussion}

Companies that were selected as samples in this study are those that have obtained HGU in Jambi Province. Overall, 
the average score for Coordination is 350.54 and is in the category of not good yet. The indicator variable in Coordination which has a relatively higher value than others is cooperation, and task distribution has lower value. The average score of Supervision is 326 and is in the category of not good. Indicator variable in Supervision that has the highest score is permitted recommendation or permit implementation, and human resources of supervisors have lower scores. The average score for Service of HGU issuance is 353.59 and is in the category of unsatisfactory. Indicator variable in the Service of HGU issuance that has the highest score is tangible, while reliability has lower score. The average score of the Company's Performance is 390.96 and is in the category of low. The indicator variable in Company's Performance that has the highest score is problem-solving, and productivity has lower score. Confirmatory Factor Analysis (CFA) was carried out to test the multidimensionality of a theoretical variable.

Table 3. Construct Reliability and Variance Extract of Variables

\begin{tabular}{|c|l|c|c|}
\hline No. & \multicolumn{1}{|c|}{ Variable } & Reliability Construct & Variance Extracted \\
\hline 1 & Coordination & 0,904 & 0,704 \\
\hline 2 & Supervision & 0,851 & 0,697 \\
\hline 3 & Service of HGU Issuance & 0,797 & 0,545 \\
\hline 4 & Company's Performance & 0,77 & 0,55 \\
\hline
\end{tabular}

Source: Processed data for the research

The results of the reliability construct of all variables are above 0.7 with the highest value in Coordinating and the lowest value in the Company's performance. Also the extracted variance value of all variables is above 0.5, with the highest value in Coordination and the lowest value in Company's Performance. This means all of these models are feasible to be tested. Test for normality data is carried out using critical ratio of skewness \pm 1.96 for Level of Significance (error rate) of $5 \%$ or \pm 2.58 for Level of Significance (error rate) of 10\%. Almost all variables have a critical ratio below \pm 1.96 or \pm 2.58 . Multivariate normality testing gives a critical ratio of 1.911 which is still lower than 1.96. A skewness index greater than 3 indicates an extreme inclination (Kline, 2004). All data, both univariate and multivariate, are in the category of normal. Outliers are the observations with a unique combination of characteristics identifiable as distinctly different from the other observations and appear in the form of extreme values, either for single variable or combination of variables (Hair, et al., 1998). Detecting multivariate outliers is done by taking into account the Mahalanobis distance. Criteria used are based on the value of chi-square with 19 degrees of freedom, which is the number of indicator variables at the significance level $p<$ 0.001 . The value of Mahalanobis distance of $\chi^{2}(19,0.001)$ is 36.19 . This means that all cases that have Mahalanobis distance value greater than 36.19 are multivariate outliers. The highest Mahalanobis distance value is 35.123 , thus there is no extreme case. So the data can be used further. The determinant of the covariance matrix is 0.004 which is relatively small, but it's not zero so it can be concluded that there is no serious multicollinearity problem in the data. All residual covariance values are close to zero which means that there is no need to modify the model developed in this study. Structural Equation Model (SEM) in full model to test model and hypothesis is carried out by goodness-of-fit test and causality test through testing of regression coefficient.

Figure 2. Full Model Analysis

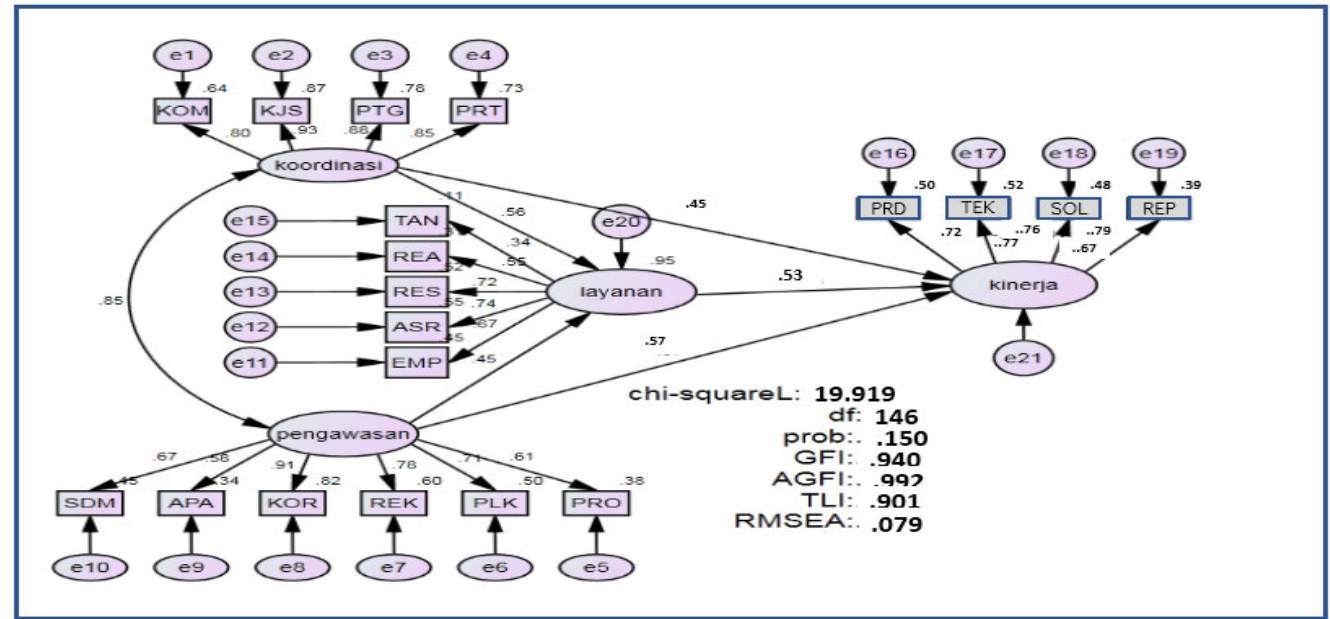

Source: AMOS output

The results of the statistical analysis support the hypothesis that the research model is fit to the data. Model fit indices are summarized in the following table: 
Table 4. Model fit indices

\begin{tabular}{|l|c|c|c|}
\hline \multicolumn{1}{|c|}{ Goodness Of Fit } & Cut Of value & Analysis Result & Model Evaluation \\
\hline Chi-Square & small & 19.919 & Good \\
Probability & $\geq 0,050$ & 0,146 & Good \\
GFI & $\geq 0,90$ & 0,940 & Good \\
TLI & $\geq 0,95$ & 0,901 & Good \\
CFI & $\geq 0,95$ & 0,961 & Good \\
CMIN/DF & $\leq 2,00$ & 0,205 & Good \\
RMSEA & $\leq 0,084$ & 0,079 & Good \\
NFI & $\geq 0,95$ & 0.968 & Good \\
Parsimony Ratio & $0-1$ & 0.654 & \\
\hline
\end{tabular}

Source: Processed primary data

Table 5. Results of Regression Weights in Structural Equation Model Analysis

\begin{tabular}{|c|c|c|c|c|c|c|c|}
\hline \multicolumn{3}{|c|}{ Causal Relation } & Coef.ß.Understand & Coef. B. std & S.E & C.R & P.value \\
\hline Service & $\begin{array}{l}<--- \\
\end{array}$ & Coordination & 0.417 & 0.564 & 0.105 & 5.371 & $* * *$ \\
\hline Service & $<---$ & Supervision & 0.461 & 0.445 & 0.141 & 3.156 & 0.001 \\
\hline Performance & $<---$ & Coordination & 0.447 & 0.445 & 0.097 & 4.588 & $* * *$ \\
\hline Performance & $<---$ & Supervision & 0.423 & 0.572 & 0.109 & 5.248 & $* * *$ \\
\hline Performance & $<---$ & Service & 0.568 & 0.529 & 0.183 & 2.891 & $* * *$ \\
\hline KOM & $<---$ & Coordination & 1.000 & 0.802 & & & \\
\hline KJS & $<---$ & Coordination & 1.217 & 0.931 & 0.283 & 3.290 & $* * *$ \\
\hline PTG & $<---$ & Coordination & 1.309 & 0.882 & 0.198 & 4.455 & $* * *$ \\
\hline PRT & $<---$ & Coordination & 1.462 & 0.851 & 0.115 & 7.400 & $* * *$ \\
\hline PRO & $<---$ & Supervision & 1.000 & 0.613 & & & \\
\hline PLK & $<---$ & Supervision & 1.334 & 0.705 & 0.178 & 3.961 & $* * *$ \\
\hline REK & $<---$ & Supervision & 1.435 & 0.777 & 0.184 & 4.223 & $* * *$ \\
\hline KOR & $<---$ & Supervision & 1.453 & 0.906 & 0.168 & 5.393 & $* * *$ \\
\hline APA & $<---$ & Supervision & 1.082 & 0.583 & 0.169 & 3.450 & $* * *$ \\
\hline SDM & $<---$ & Supervision & 1.097 & 0.673 & 0.152 & 4.428 & $* * *$ \\
\hline EMP & $<---$ & Service & 1.000 & 0.673 & & & \\
\hline ASR & $<---$ & Service & 1.133 & 0.74 & 0.134 & 5.522 & $* * *$ \\
\hline RES & $<---$ & Service & 0.955 & 0.722 & 0.117 & 6.171 & $* * *$ \\
\hline REA & $<---$ & Service & 0.575 & 0.554 & 0.088 & 6.295 & $* * *$ \\
\hline TAN & $<---$ & Service & 0.304 & 0.338 & 0.075 & 4.507 & $* * *$ \\
\hline PRD & $<---$ & Performance & 1.000 & 0.723 & & & \\
\hline TEK & $<---$ & Performance & 0.875 & 0.77 & 0.276 & 2.790 & 0.002 \\
\hline SOL & $<---$ & Performance & 0.785 & 0.756 & 0.311 & 2.431 & 0.011 \\
\hline REP & $<---$ & Performance & 0.646 & 0.794 & 0.188 & 4.223 & $* * *$ \\
\hline
\end{tabular}

Source: AMOS output

Results of the Full Model test indicates the model is fit. The results meet almost all the criteria. Each indicator variable shows the result that meets the criteria of a CR value above 1.96 with a P label less than 0.05 and lambda value or loading factor greater than 0.5 . These indicator variables are indicator of the constructed latent factors. Thus the model in this study can be accepted. The strength of relationship between variables, both direct influence, indirect influence, and the total influence of the research model can be seen as follows:

Table 6 Direct Influence, Indirect Influence, and Total Influence

\begin{tabular}{|l|c|c|c|}
\hline \multicolumn{1}{|c|}{ Variable } & $\begin{array}{c}\text { Direct } \\
\text { Influence }\end{array}$ & Indirect Influence & $\begin{array}{c}\text { Total } \\
\text { Influence }\end{array}$ \\
\hline $\begin{array}{l}\text { Coordination on Company's Performance } \\
\text { through Service of HGU issuance }\end{array}$ & - & $0,56 \times 0,53=0,297$ & 0,297 \\
\hline Coordination on Company's Performance & 0,45 & & 0,450 \\
\hline $\begin{array}{l}\text { Supervision on Company's Performance } \\
\text { through Service of HGU issuance }\end{array}$ & - & $0,45 \times 0,53=0,315$ & 0,239 \\
\hline Supervision on Company's Performance & 0,57 & & 0,57 \\
\hline
\end{tabular}

Source: AMOS output

The direct influence of Coordination on Company's Performance is 0.45 and of Supervision on Company's

Performance is 0.57 . These findings indicate that Coordination and Supervision have a direct influence on the Company's performance. This means that the performance of HGU holder companies in Jambi Province, besides 
being directly determined by coordination, is also determined by internal supervision of the agencies involved in the issuance of HGU. It shows that both variables contribute to the improvement of company's performance. To analyze the indirect influence of Coordination on Company's Performance, it can be seen from the total influence of 0.746 and the direct influence of 0.450 , so there is an indirect effect of 0.297 . These findings show in general that the direct influence of coordination on the performance of HGU holder company is greater than its indirect influence. The effect of Coordination on the Performance of HGU holder company is mediated by one variable, Service of HGU issuance. As for the effect of Supervision on Company's Performance, its direct effect $(0.57)$ is greater than its indirect effect through Service of HGU issuance which is only 0.239.

\section{Discussion}

In this study, coordination, supervision, and service for HGU issuance are not good yet Coordination that has been carried out in the form of communication, cooperation, task distribution, and meetings has not worked as expected. Supervision by agencies related to HGU issuance also does not work well. Permit recommendation or implementation that is related to the regularity of National Land Agency (BPN or Badan Pertanahan Nasional) conducting supervision and the regularity of companies reporting are still not good. Service of HGU issuance by National Land Agency has not satisfied the HGU holder companies and is not in line with the expectations of the HGU holder companies. The results of the performance of HGU holder companies based on the statements before indicate that the performance of the companies is not in line with expectations. Therefore, coordination between agencies/institutions related to $\mathrm{HGU}$ issuance, internal supervision related to $\mathrm{HGU}$ issuance, service of $\mathrm{HGU}$ issuance and the performance of HGU holder companies in Jambi Province should be improved, especially in managing permits and obtaining land rights, especially Right to Cultivate (HGU or Hak Guna Usaha).

\section{Influence of Coordination between Agencies/Institutions related to HGU issuance on Service of HGU issuance}

Coordination from agencies or institutions related to the issuance of requirements for the application of HGU to $\mathrm{BPN}$ has a positive and significant impact on the HGU issuance. Coordination between agencies related to institutional coordination mechanisms, authority and power as the basis for interaction and resources, and the relationship between Provincial Office of BPN, PTSP, Regent, Land Office, KUH Office, TKPRD, Provincial Forestry Office (Dinas Kehutanan Provinsi), BPBD, EMR Office (Dinas ESDM), Chief of Village, Plantation Office, Banks, and Private Parties are mutual interdependence coordination. It turns out that all of them have an impact on the service provided by the Regional Office of BPN Jambi Province. These findings are in line with the results of Mintzberg's (1997) study, whose results concluded that coordination did indeed have a positive and significant effect on service. As coordination progresses well, quality of service will also increase. Another study by Alexander (1995), titled The Effect of Coordination on Service, showed that coordination did have a positive and significant effect on service.

Influence of Supervision of Agencies/Institutions related to HGU issuance on the Service of HGU issuance From the results of this study, it can be seen that the supervision of agencies related to the HGU issuance has a positive and significant impact on the service of HGU issuance. Supervision in this study includes activities ranging from making a supervision program, implementation of supervision, permits recommendation or implementation, coordinating in supervision of permits issued, improving the ability of its apparatus, to pay attention to human resources carrying out HGU supervision. The procedures to supervise the issuance of HGU by National Land Agency, preceded by making a supervision program and followed by the implementation of supervision activities as well as the cooperation of the HGU holder company to provide reports on any matters relating to their HGU, will be able to proceed well if they are accompanied by coordination and good ability of apparatus on supervising. If all aspects of the supervision are carried out properly, of course, it will have an impact on improving the quality of service provided to HGU holder companies. These findings are in line with a survey conducted by Sheridan (2012), whose survey results showed that supervision had a significant and positive relation to service, voluntary turnover and commitment of organization. In line with the results of this study as well, Stoner, Freeman \& Gilbert (2005: 114) stated that the success of an organization depends very much on its success in creating specific supervision as part of a strategic plan. Furthermore, they stated that conformity of the organization with supervision has an effect on its service.

\section{The Influence of Coordination between Agencies/Institutions related to HGU Issuance on the Performance of HGU holder companies}

Coordination between agencies or institutions related to the issuance of requirements for the application of HGU to BPN has a positive and significant impact on the performance of HGU holder companies. Through good coordination between related agencies/institutions as well as between related agencies/institutions and company, it will create work spirit for HGU holder companies. It is because companies find no obstacles in fulfilling the 
requirements for the issuance of HGU. Good communication and good cooperation between related agencies or institutions and the company are expected to be able to improve the overall company's performance as shown by increasing productivity. If coordination does not go well, the expected increase in productivity or the improvement or the company's reputation, as well as the increase in problem-solving ability will be difficult to be realized. These findings are in line with the opinion of Arnaud and Schminke (2007), that the placement of each element in an organization must have its own properness which positively influences performance. Interactions of various components inside and outside the organization are represented by coordination. Internally, coordination means setting rules and standards based on cooperation. Externally, coordination means building relationships and interest aggregation. Improvement of relationship between individual and between groups guarantees performance with trust. These findings are also in line with the results of the research of Omoregie Charles Osifo (2013), where coordination can help improve trust on organization in various ways. Trust is part of performance as it is the foundation and performance instrument/value. Coordination can help increase internal and external trust. Internally, better interaction leads to better cooperation, and better cooperation leads to higher trust. Externally, better interaction leads to focus, focus leads to komparatif cost or competitive advantage and goodwill. An increase in trust has an impact in increasing organizational performance because trust is performance. Coordination is important as it is related to internal and external aspects of organizational performance.

\section{The Influence of Supervision of Agencies/Institutions related to HGU issuance on the Performance of HGU holder Companies}

Internal supervision of agencies/institutions related to the issuance of requirements for the application of HGU to BPN has a positive and significant impact on the performance of HGU holder companies. If all aspects of supervision are carried out properly, it will increase the performance of HGU holder companies. Through good supervision by related agencies/institutions, it will clearly be able to raise confidence of the companies. Companies will be sure that there are parties who provide an evaluation if there are things that are contrary to the HGU implementation. This will lead to prudential attitude of companies in implementing various policies relating to their HGU land. As a consequence of this attitude, it is expected to be able to improve company's performance. Conversely, if supervision does not go well, the company will believe that they will not get an evaluation from agencies/institutions related to HGU issuance. So in their operation activities, it is possible that their policies are not in accordance with what they are supposed to do. Eventually supervision is also one of the ways to control the activities of companies that have obtained permits before applying for HGU. Many companies are found to have obtained permits but they do not continue to apply for their Right to Cultivate (HGU). It is a disadvantage to the State because illegal companies able to operate and not contribute to state income, as well as trigger land conflicts between masyarakat hukum adat (indigenous communities) and plantation companies. These findings are in line with Thompson's theory (1991), developed by Peters (1998), one of which is Coordination with Hierarchy-TypeMechanism (HTM) referring to a coordination mechanism based on authority and dominance. This study is also in line with research conducted by Verhoest Koen, Peters Guy, Beuselinck Eva, Meyers Falke, and Bouckaert Geert (2014) titled How Coordination and Control of Public Organizations by Government Interrelate: An Analytical and Empirical Exploration. Supervision is imposed on bureaucratic organizations, although organizations may have the capacity to take certain policies effectively. The direct implementation of this authority will result in coordination which will be developed by government to be procedural mechanisms (such as Standard Operating Procedure/SOP) to achieve a common goal. Control is carried out through detailed regulations, SOP and prior approval from other agencies before applying for HGU in Land Office and Regional Office of BPN as public service organizations that are still part of the hierarchy of the Ministry of Agrarian Affairs and Spatial Planning/National Land Agency. In order to stay compliant with government policies, the minister has the right to veto any decision before it is implemented and can block decisions that appear to be inconsistent with laws, regulations and public interest. In addition, as a public organization, slow service flow of the system affects work system of service users as they cannot proceed to the next stage of business due to the problems with permits. These findings are in line with research conducted by Elly Nielwaty, Prihati and Sulaiman Zuhdi (2017) that showed supervision had a significant and positive relation to company's performance.

\section{The Influence of Service of HGU issuance on Performance of HGU holder Companies}

Service of HGU issuance by BPN has a positive and significant impact on the performance of HGU holder companies. The issuance of HGU by BPN Jambi Province is expected to be able to encourage the HGU holder companies to truly utilize all rights they have received and cultivate land in accordance with its allotment. If the realization is in line with expectations, it will certainly be able to increase the work spirit for companies to do their business and in turn, it will also improve overall company's performance. These findings are in line with Law No. 25/2007 concerning Investment which is expected to attract investors. Assurance of this facility encourages more detailed regulations of fiscal facilities, land rights, immigration, and import permits. It is also in line with research conducted by Wahana Grahawan Manurung, Budiman Ginting, Mahmul Siregar, and T. Keizerina Devi A. (2019), 
titled Analysis of Foreign Investor Protection in Investment Activities in North Sumatra. The results of their study apparently stated that the policies in investment sector must be accompanied by adequate legal arrangements aimed at enhancing the role of the legal system, one of which is to regulate coordination between institutions. This orderly coordination between relevant agencies in HGU service will provide clarity and certainty in fulfilling investor's obligations and creating business efficiency as well as improve company's performance in investing. A research by Kuncoro (2005) showed that the attractiveness of investment/business activities is more influence by noneconomic factors, especially Institutional, Physical Infrastructure, and Social Politics, compared to non-economic factors such as Regional Economy and Labor. He also stated that three main things that investors and entrepreneurs want in order to improve company's performance are simplification of systems and permits, reduction of various overlapping tax, and transparency of licensing costs.

\section{Conclusions and Recommendations}

\section{Conclusions}

Coordination between agencies related to the issuance of Right to Cultivate, supervision of agencies related to HGU issuance, service of HGU issuance, and performance of HGU holder companies in Jambi Province have not run as expected and have not been carried out in line with the expectations of the HGU holders. As a result, HGU holder companies do not have good performance yet. Based on the results of this study, conclusions can be seen as follows:

1. Coordination of agencies/institutions related to the issuance of requirements for the submission of HGU to BPN has a positive and significant impact on the service of HGU issuance.

2. Supervision of HGU issuance has a positive and significant impact on the service of HGU issuance.

3. Coordination of agencies/institutions related to the issuance of requirements for the submission of HGU to BPN has a positive and significant impact on the performance of HGU holder companies.

4. Internal supervision of agencies/institutions related to the issuance of requirements for the submission of HGU to BPN has a positive and significant impact on the performance of HGU holder companies.

5. Service of HGU issuance by BPN has a positive and significant impact on the performance of HGU holder companies.

\section{Recommendations}

Based on the conclusions above, coordination between agencies/institutions related to HGU issuance, internal supervision related to $\mathrm{HGU}$ issuance, service of $\mathrm{HGU}$ issuance, and the performance of HGU holder companies in Jambi Province should be improved in the future, especially in managing permits and obtaining land rights. It is in order to make plantation companies in Jambi Province can doing their business comfortably so that there is no longer an imbalance number of area with Location Permit, Plantation Business License (IUP or Izin Usaha Perkebunan) and Right to Cultivate (HGU or Hak Guna Usaha). More in-depth study on existing theories as the basis for improving the performance of HGU holder companies is necessary, as well as further research to find other variables besides Coordination and Supervision on Service of HGU issuance.

Due to weakness in the implementation of some principles of coordination and supervision, it is necessary to develop implementation and technical guidelines that support the effective implementation of coordination and supervision in the service of HGU issuance. These guidelines are made to make sure the service provided is not complicated, time- and cost-consuming, causing public dissatisfaction and doubt about the ability of the apparatus. In the end, the company as the user of this service will be more focused on doing business and improving its performance.

\section{References}

Alexander, Ernest R. (1995). How Organization Act Together: Interorganizational Coordination in Theory and Practice, Amsterdam, Netherland: Gordon and Breach Publishers.

Alter, C. \& Hage. (1993). I. New Burry Park. CA: Sage. Dalam Jones, Candace, et al. 1997. A general Theory of Network Governance: Exchange Conditions and Social Mechanisms. Academy Of Management, The Academy Of Management Review: Proquest.

Anthony dan Govindarajan, 2002, Sistem Pengendalian Manajemen. Salemba Empat. Jakarta.

Bailis, L. (1989). As assessment of the JTPA role in state and local coordination activities: Report on the literature review. Washington, DC: James Bell Associates.

Burbridge, L.C. \& Nightingale, D.S, (1989). Local coordination of employment and training services to welfare recipients. Washington, DC: The Urban Institute.

Dwiyanto, Agus. (2006). Transparansi Pelayanan Publik”, dalam Agus Dwiyanto,ed .2006. Mewujudkan Good Governance Melalui Pelayanan Publik. Yogyakarta: Gadjah Mada University Press.

Edward, (2008). Studi Proses Sistem Kontrol Dalam Meningkatkan Kinerja Tenaga Penjual: Sebuah Pengembangan Model Teoretikal dan Pembuktian Empirik pada Perusahaan-perusahaan Industri 
Pengolahan di Jawa Tengah, Universitas Diponegoro, Semarang.

Elly Nielwaty, Prihati, Sulaiman Zuhdi, (2017). Pengaruh Pengawasan Terhadap Kinerja Pegawai Disperindag Sub Bidang Pengawasan Barang Dan Jasa Provinsi Riau. Jurnal Niara. Vol 10 No 1 Juli 2017.

Ernie Tisnawati Sule, Kurniawan Saefullah. (2008). Pengantar Manajemen. Kencana Prenada Media Group. Jakarta.

Galbraith, J. R., (1977). Organization design. Reading, MA: Addison-Wesley.

Griffin, R. (2004). Manajemen. Terjemahan Gina Gania. Jakarta: Erlangga.

Griffin, R. W., \& Ebert, R. J, 2006, Bisnis. Jakarta: Erlangga.

Harold Koontz, Cyril O’Donnell \& Heinz Weihrich. (1996). Manajemen; Jilid 1 Edisi Kedelapan Oleh.-Jakarta: Erlangga.

Hessel Nogi S, Tangkilisan. (2005). Manajemen Publik. Jakarta: PT. Gramedia Widiasarana.

Imam Ghozali. (2017). Model Persamaan Struktural SEM dengan AMOS, Badan Penerbit Universitas Diponegoro, Semarang

Pemerintah Provinsi Jambi. (2019), Jambi Dalam Angka 2018.

Keban, T. Yeremias. (2004). Enam Dimensi Strategis Administrasi Publik, Konsep, Teori dan Isu. Gava Media. Yogyakarta.

Malone, T.W. \& Crowston, K. (1994). The interdisciplinary study of coordination, Computing Surveys, 26(1): 87119 diambil Maret 2011 dari http://ccs.mit.edu/papers/CCSWP-157.html.

Martinson, Karin. (1999). Literature Review on Service Coordination and Integration in the Welfare and Workforce Development Systems, Washington, DC: The Urban Institute

Mathar, Fadhilah. (2012). Pemanfaatan Teknologi Dalam Menunjang Implementasi Good Governance di Badan Layanan Umum Pemerintah, Jurnal jptinformatikadd120108, Universitas Islam Negeri Syarif Hidayatullah, Jakarta.

Mintzberg, H. (1997). Managing Government, Governing Management. Harvard Business Review 74(3): $75-83$.

Mudrajad Kuncoro. (2005). Daya Tarik Investasi Dan Pungli Di DIY, Jurnal Ekonomi Pembangunan, Universitas Gajah Mada, Yogyakarta.

Nazarudin (2016). Pengaruh Koordinasi dan Pengawasan Terhadap Efektivitas Organisasi Di Lingkungan Pemerintahan Kabupaten Cianjur (Studi pada Sekretariat-sekretariat, Lembaga Teknis Daerah dan DinasDinas di Lingkungan Pemerintahan Kabupaten Cianjur), Program Doktor Ilmu Sosial Fakultas Pascasarjana Universitas Pasundan Bandung.

Osifo O., Charles. (2013).The Effects of Coordination on Organizational Performance: An Intra and Inter Perspective. University of Vaasa Faculty of Philosophy, Asian Journal of Business and Management (ISSN: 2321 - 2803) Volume 01- Issue 04, October 2013. Public Management.

R.Terry, George. (2006). Prinsip- Prinsip Manajemen. Jakarta: Bumi Aksara.

Simamora. (2001). Memenangkan Pasar dengan Pemasaran Efektif dan Profitabel, Edisi Pertama, Jakarta, PT. Gramedia Pustaka Utama.

Simanjuntak, Manlian Ronald A; Gusfica. (2018). Kajian Awal Peran Koordinasi Dalam Proses Konstruksi Untuk Mengantisipasi Keterlambatan Pada Proyek X, Konferensi Nasional Teknik Sipil, Konferensi Nasional Teknik Sipil 12Batam, 18-19 September2018 ISBN: 978-602-60286-1-7

Slavkovic Marco, Babic Verica. (2013). Knowledge management, innovativeness, and organizational performance: Evidence from Serbia, Ekonomski anali, Serbia.

Snell, S. A. (1992). Control Theory In Strategic Human Resource Management: The Mediating Effect Of Administrative Information. Academy of Management Journal, 35, 292-327.

Sri Mifti, Nugroho Budi Lestariyo. (2009). Anacostia Kowanda, Pengawasan Internal Dan Kinerja (Suatu Kajian Di Kantor Inspektorat Jenderal Departemen Dalam Negeri), Jurnal Ekonomi Bisnis No. 3 Vol. 14, Agustus 2009, Universitas Gunadarma.

Stoner, James A.F; Charles Wankel. (1986). Management. Englewood Cliffs. New Jersey: Prentice-Hall International, Inc. p. 263

Stoner, James AF \& R Edward Freeman. (1994). Manajemen. Edisi Kelima. Jilid 2. Jakarta:Intermedia.

Sugandha, Dann. (1991). Koordinasi Alat Pemersatu Gerak Administrasi. Jakarta : Intermedia.

Sutarto, (2006). Dasar- Dasar Kepemimpinan Administrasi. Yogyakarta: Gadjah Mada University Press

Tambunan, R. (2008). Analisis Peran Internal Auditor dalam Mempengaruhi Peningkatan Kinerja Operasional Unit Kerja pada BUMN Perkebunan Di Propinsi Sumatera Utara. Tesis Magister Ilmu Ekonomi Akuntansi. USU eRepository C 2008. http://library.usu.ac.id.

Thompson, G.,J. Frances, R. Levacic and J. Mitchell. (1991) Markets, Networks and Hierarchies. London: Sage Verhoest Koen, Peters Guy, Beuselinck Eva, Meyers Falke and Bouckaert Geert. (2014). How coordination and control of public organizations by government interrelate: an analytical and empirical exploration, Conference Proceedings International, KU Leuven - University of Leuven, Nederlands

Wahana Grahawan Manurung, Budiman Ginting, Mahmul Siregar, T. Keizerina Devi A. (2019). Analisis 
Terhadap Perlindungan Investor Asing Dalam Kegiatan Penanaman Modal Di Sumatera Utara (Studi Putusan MA-RI NO. 382 K/TUN/2010), Universitas Sumatera Utara, Medan

Zeithaml, V. Parasuraman, A. \& L. Berry L. (1985). Problems and Strategies in Services Marketing”. Jurnal of Marketing Vol. 49. Spring. 